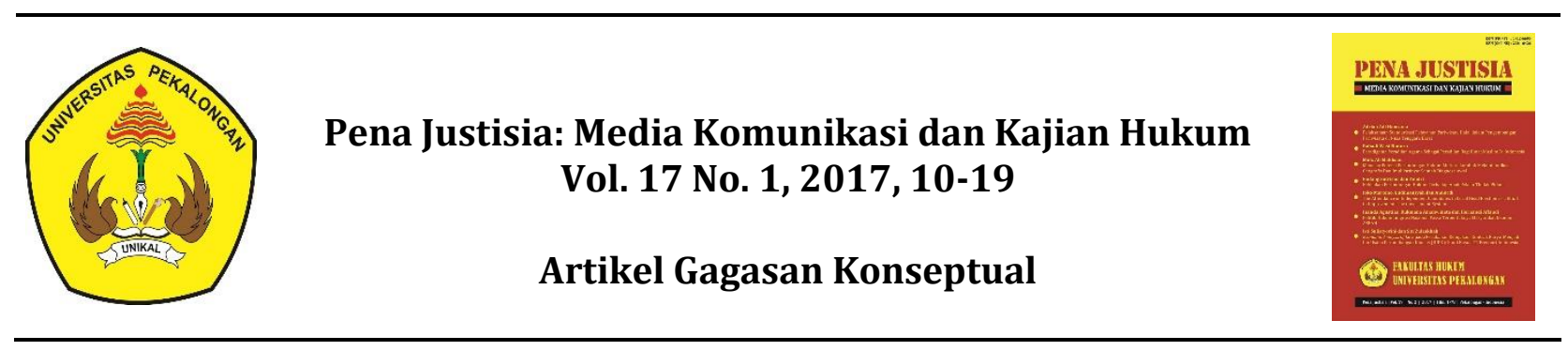

\title{
Implementasi Asas-Asas Umum Pemerintahan yang Baik Di Lingkungan Peradilan Administrasi Negara
}

\author{
Ichsan Syuhudi \\ Fakultas Hukum Universitas Pekalongan, Indonesia
}

Artikel Diterima:

12 April 2017

Artikel Disetujui:

17 Mei 2017

Artikel Diterbitkan:

10 Juni 2017

\begin{abstract}
A fundamental principle within a democratic constitutional state is that the organ of the ruler without any basis in the provisions of the law shall have no authority which may affect or alter the legal circumstances of the citizens. The special authority of the rulers against the people is solely on the basis of a law order. One of the benchmarks for assessing whether government action is in line with the rule of law or not is to use appropriate general principles of governance. It is technically operational that the process pursued by state administrative law when applying the appropriate general principles of government as a test instrument to the administrative decisions of the state has several elements in common with the process of applying the law in civil courts. In applying the general principles of decent governance as a means of testing the validity of the decisions of state administration can be approached with three perspectives to discuss them, namely historical, theoretical and practical juridical.
\end{abstract}

Keywords: General Principle of Good Governance, Administrative Court, Freies Ermessen

\section{Abstrak}

Suatu asas pokok dalam dalam negara hukum yang demokratis adalah bahwa organ penguasa itu tanpa adanya dasar dalam ketentuan undangundang tidak akan memiliki wewenang yang dapat mempengaruhi atau mengubah keadaan hukum warga masyarakat. Wewenang khusus penguasa terhadap warga masyarakat itu semata-mata atas dasar perintah undangundang. Salah satu tolok ukur untukmenilai apakah tindakan pemerintah itu sejalan dengan negara hukum atau tidakadalah dengan menggunakan asasasas umum pemerintahan yang layak. Secara teknis operasional, bahwa proses yang ditempuh oleh hukum administrasi negara pada saat menerapkan asas-asas umum pemerintahan yang layak sebagai alat uji terhadap keputusan administrasi negara mempunyai beberapa unsur kesamaan dengan proses penerapan hukum di pengadilan perdata. Dalam penerapan asas-asas umum pemerintahan yang layak sebagai alat uji terhadap keabsahan keputusan administrasi negara dapat didekati dengan tiga sudut pandang untuk membahasnya yaitu historis, teoritis dan yuridis praktis.

Kata Kunci : AAUPB, Peradilan Administrasi, Freies Ermessen 


\section{PENDAHULUAN}

Negara Kesatuan Republik Indonesia merupakan negara hukum yang berdasarkan Pancasila dan Undang-Undang Dasar Republik Indonesia Tahun 1945, yang bertujuan untuk mewujudkan tata kehidupan bangsa, negara dan masyarakat yang tertib, bersih, makmur dan berkeadilan. Suatu asas pokok dalam dalam negara hukum yang demokratis adalah bahwa organ penguasa itu tanpa adanya dasar dalam ketentuan undangundang tidak akan memiliki wewenang yang dapat mempengaruhi atau mengubah keadaan hukum warga masyarakat. Dengan kata lain semua wewenang hukum administrasi negara harus bersumber pada peraturan-peraturan umum yang mengikat. Dalam peraturan-peraturan yang demikian itu organ yang berwenang ditunjuk atau ditentukan serta wewenangnya dirumuskan. ${ }^{1} \mathrm{Hal}$ inilah yang dinamakan asas wetmatigheid/ legalitas dari pemerintahan.

Setiap stelsel hukum diakui, bahwa wewenang khusus penguasa terhadap warga masyarakat itu semata-mata atas dasar perintah undang-undang. Jadi semua wewenangnya untuk melakukan perbuatan hukum administrasi, bentuk di dalam mana perbuatan hukum dilakukan dan isi dari hubungan hukum yang diciptakannya harus bersumber pada peraturan perundangundangan. Wewenang untuk menetapkan besarnya pajak seseorang, untuk mencabut SIM umpamanya harus berdasar pada ketentuan yang tegas dalam pengaturan hukum tertulis yang mengikat secara umum.

Namun dalam pelaksanaannya masih terdapat kesulitan, walaupun wewenangnya sendiri itu selalu dirumuskan dalam peraturan tertulis, namun tetap banyak keanekaragaman dalam perumusan tentang cara-cara wewenang-wenang tersebut dilaksanakan. Di samping pengaturan yang mendetail tentang isi maupun bentuk perbuatan-perbuatan hukum yang dapat dilakukan berdasar pada peraturan tersebut, terdapat pula

Paulus Effendi Lotulung, 1994, Perbandingan Hukum Administrasi Negara, Bandung: PT. Citra aditya Bakti, hlm.143 pengaturan lain yang semata-mata hanya menentukan tentang wewenang saja. Dalam hal demikian itu, maka teori hukum umum dan yurisprudensi dari instansi-instansi banding yang berwenang harus menentukan mana yang boleh dan mana yang tidak boleh dilakukan dalam kerangka pelaksanaan wewenang tersebut. Jadi tanpa peraturan tertrulis wewenang tersebut tidakmungkin akan adad wewenang, tetapi kalau wewenang tersebut dirumuskan secara sumir/tidak tegas/ samar atau dengan kata-kata yang bersifat umum, maka teori hukum dan yurisprudensi yang menentukan sampai seberapa jauh jangkauan dari wewenang tersebut. ${ }^{2}$ Sebagai contoh dalam peraturan ini: "Tanpa izin Walikota dilarang berjualan di jalan protokol". Adanya peraturan tersebut lahirlah wewenang Walikota untuk mengeluarkan izin. Apakah wewenang itu juga mencakup untuk mencabut izin yang telah dikeluarkan. Rasanya akan berkata ya. Tetapi apakah pencabutan demikian dapat ia lakukan sembarang waktu tanpa melalui prosedur apa-apa yang berarti tanpa melahirkan kepentingan si pemegang izin. Jawabnya akan bisa diberikan oleh asas-asas umum pemerintahan yang baik, yang dikembangkan baik oleh ilmu hukum maupun yurisprudensi. Jadi jelas bahwa sering undang-undang dalam penerapannya harus dilengkapi oleh norma-norma hukum yang tidak tertulis. Dengan demikian, bagi penguasa untuk mengetahui dasar wewenangnya untuk dapat melakukan perbuatan hukum administrasi harus selalu mencari dalam hukum tertulis maka dalam melaksanakan wewenangnya harus berpedoman/mengarahkan kepada ajaranajaran yang telah dikembangkan baik dalam lingkungan administrsisendiri maupun oleh putusan-putusan pengadilan. Ajaran-ajaran inilah yang dinamakan algemene beginselen van behoorlijk bestuur, principles of natural justice, lespriciples generaux de droit coutumier public atau yang dikenal dengan nama asas-asas umu pemerintahan yang baik.

2 Ibid, hlm. 144 
11 Pena Justisia: Media Komunikasi dan Kajian Hukum

Vol. 17, No. 1, 2017

Menurut Sjahran Basah, bahwa pemerintah dalam menjalankan aktifitasnya terutama dalam mewujudkan tujuan-tujuan negara (bestuurzorg) melalui pembangunan, tidak berarti dapat bertindak semena-mena, melainkan sikap tindak itu haruslah dipertanggungjawabkan. Artinya meskipun intervensi pemerintah dalam kehidupan warga negara merupakan kemestian bagi konsepsi welfare state, akan tetapi pertanggungjawaban setiap tindakan pemerintah juga merupakan kemestian dalam negara hukum yang menjunjung tinggi nilai-nilai kebenaran dan keadilan. Konsepsi negara hukum mengindikasikan ekuilibirum antara hak dan kewajiban. Salah satu sarana untuk menjaga ekuilibirum adalah melalui peradilan administrasi, sebagai peradilan khusus yang berwenang dan menyelesaikan sengketa antara pemerintah dengan warga negara. Salah satu tolok ukur untukmenilai apakah tindakan pemerintah itu sejalan dengan negara hukum atau tidakadalah dengan menggunakan asas-asas umum pemerintahan yang layak. ${ }^{3}$

\section{RUMUSAN MASALAH}

Berdasarkan pada uraian tersebut di atas, permasalahan yang dikaji dalam artikel ini adalah bagaimana implementasi asas-asas umum pemerintahan yang baik dalam lingkungan peradilan administrasi negara?

\section{PEMBAHASAN}

\section{Konsepsi Dasar Asas-asas Umum Pemerin- tahan Yang Baik}

Sejak dianutnya konsepsi welfare state, yang menempatkan pemerintah sebagai pihak yang bertanggung jawab terhadap kesejahteraan umum warga negara dan untuk mewujudkan kesejahteraan ini, pemerintah diberi wewenang untuk campur tangan dalam segala lapangan kehidupan masyarakat, yang dalam campur tangan tersebut tidak saja berdasarkan pada peraturan perundang-undangan tetapi dalamkeadaan ter- tentu dapat bertindak tanpa bersandar pada peraturan perundang-undangan tetapi berdasarkan inisiatif sendiri melalui Freies Ermessen, ternyata menimbulkan kekhawatiran di kalangan warga negara. Karena dengan Freies Ermessen muncul peluang terjadinya benturan kepentingan antara pemerintah dengan rakyat baik dalam bentuk onrechtmatige overheidsdaad, detournement de pouvoir, maupun dalam bentuk willekeur, yang merupakan bentuk-bentuk penyimpangan tindakan pemerintahan yang mengakibatkan terampasnya hak-hak asasi warga negara. Guna menghindari atau meminimalisir terjadinya benturan tersebut, pada tahun 1946 Pemerintah Belanda membentuk komisi yang dipimpin oleh de Monchy yang bertugas memikirkan dan meneliti beberapa alternatif tentang Verhoogde Rechtsbescherming atau peningkatan perlindungan hukum bagi rakyat dari tindakan administrasi negara yang menyimpang. Pada tahun 1950 komisi de Monchy kemudian melaporkan hasil penelitiannya tentang verhoogde rechtsbescherming dalam bentuk "algemene beginselen van behoorlijk bestuur" atau asasasas umum pemerintahan yang layak. Hasil penelitian komisi ini tidak seluruhnya disetujui pemerintah atau beberapa hal yang menyebabkan perbedaan pendapat antara komisi den Monchy dengan pemerintah, yang menyebabkan komisi ini dibubarkan pemerintah sebelum dapat menyelesaikan tugasnya. Kemudian muncul komisi van de Greenten, yang juga bentukan pemerintah dengan tugas yang sama den de Monchy. Namun komisi kedua ini juga mengalami nasib yang sama, yaitu karena ada beberapa pendapat yang diperoleh dari hasil penelitian tidak disetujui oleh pemerintah dan komisi inipun dibubarkan tanpa membuahkan hasil. ${ }^{4}$

Pemerintah Belanda tidak sepenuh hati dalam upaya mewujudkan peningkatan perlindungan hukum bagi rakyat dari tindakan administrasi negara. Terbukti dengan dibubarkannya dua panitia tersebut, ditambah pula dengan mun-

3 Ridwan, HR, 2002, Hukum Administrasi Negara, Yogyakarta: Penerbit UII Press, hlm.188 
culnya keberatan dan kekhawatiran di kalangan pejabat dan para pegawai pemerintahan di Nederland karena dikhawatirkan asas-asas ini akan digunakan sebagai ukuran untuk menilai kebijakan-kebijakan pemerintah. Meskipun demikian, ternyata hasil penelitian de Monchy ini digunakan dalam pertimbangan putusan-putusan Raad van State dalam perkara administrasi. Seiring dengan perjalanan waktu, keberatan dan kekhawatiran tersebut akhirnya hilang, bahkan sekarang telah diterima dan dimuat dalam berbagai peraturan perundang-undangan di Nederland. ${ }^{5}$

\section{Kedudukan Asas-asas Umum Pemerintahan Yang Baik dalam Sistem Hukum}

Pemahaman terhadap asas-asas umum pemerintahan yang baik tidak dapat dilepaskan dari konteks kesejarahan, di samping dari segi kebahasaan. Hal ini karena asas ini muncul dari proses sejarah, sebagaimana tersebut di atas. Terlepas dari kenyataan bahwa kemudian asas-asas umum pemerintahan yang baik ini menjadi wacana yang dikaji dan berkembang di kalangan para sarjana sehingga melahirkan rumusan dan interpretasi yang beragam, guna pemahaman awal kiranya diperlukan pengertian dari konteks kebahasan dan kesejarahan. Dengan bersandar pada kedua konteks ini, asas-asas umum pemerintah yang baik dapat dipahami sebagai asas-asas umum yang dijadikan sebagai dasar dan tata cara dalam penyelenggaraan pemerintahan yang layak, yang dengan cara demikian penyelenggaraan pemerintahan itumenjdi baik, sopan, adil dan terhormat, bebas dari kezaliman, pelanggaran peraturan, tindakan penyalahgunaan wewenang dan tindakan sewenang-wenang.

Asas-asas umum pemerintahan yang baik berkembang menjadi wacana yang dijadikan kajian para sarjana dan ini menunjukkan bahwa AAUPB merupakan konsep terbuka (open begrip). Sebagai konsep terbuka, maka akanberkembang

5 SF. Marbun,1997, Peradilan Administrasi dan Upaya Administratif di Indonesia,, Yogyakarta: Liberty, hlm.355

6 Jazim Hamidi, 1999, Penerapan Asas-asas Umum Penyelenggaraan Pemerintahan yang Layak (AAUPL) di Ling- dan disesuaikan dengan ruang dan waktu dimana konsepini berada. Atas dasar ini tidaklah mengherankan jika secara kontemplatif maupun aplikatif AAUPB/AAUPL ini berbeda-beda antara satu dengan lainnya. Berdasrakan penelitian, Jazim Hamidi menemukan AAUPL sebagai berikut: Pertama, Asas-asas umum pemerintahan yang layak merupakan nilai-nilai etik yang hidup dan berkembang dalam lingkungan hukum administrasi negara; Kedua, Asas-asas umum pemerintahan yang layak berfungsi sebagai pegangan bagi pejabat administrasi negara dalam menjalankan fungsinya, merupakan alat uji bagi hakim administrasi dalam menilai tindakan administrasi negara (yang berwujud penetapan/beschikking) dan sebagai dasar pengajuan gugatan bagi pihak penggugat; Ketiga, sebagian besar dari AAUPL masih merupakan asas-asas yang tidak tertulis, masih abstrak dan dapat digali dalam praktek kehidupan di masyarakat; Keempat, sebagian asas yang lain sudah menjadi kaidah hukum tertulis dan terpencar dalam berbagai peraturan hukum positif. Meskipun sebagian dari asas itu berubah menjadi kaidah hukum tertulis, namun sifatnya tetap sebagai asas hukum. ${ }^{6}$

Menurut Van Wijk/Willem Konijnenbelt dan ten Berge bahwa kedudukan Asas-asas Umum Pemerintahan yang Layak dalam sistem hukum adalah sebagai hukum tidak tertulis. Selain itu Philipus M. Hadjon mengatakan bahwa asas-asas umum pemerintahan yang layak harus dipandang sebagai norma-norma hukum tidak tertulis, yang senantiasa harus ditaati oleh pemerintah, meskipun arti yang tepat dari asas-asas umum pemerintahan yang layak bagi tiap keadaan tersendiri tidak selalu dapat dijabarkan dengan teliti. Dapat pula dikatakan bahwa asas-asas umum pemerintahan yang layak adalah asas-asas hukum tidak tertulis dari mana untuk keadaan-keadaan tertentu dapat ditarik aturan-aturan hukum yang dapat diterapkan. ${ }^{7}$ Sebenarnya menyamakan

kungan Peradilan Administrasi Indonesia, Citra aditya Bakti, Bandung, hlm. 24

7 Philipus M. Hadjon, 1993, Pengantar Hukum Administrasi Negara Indonesia, Yogyakarta: Gadjah Mada University Press, hlm. 270 
13 Pena Justisia: Media Komunikasi dan Kajian Hukum

Vol. 17, No. 1, 2017

asas-asas umum pemerintahan yang layak dengan norma hukum tidak tertulis dapat menimbulkan salah paham, sebab antara "asas" dengan "norma" terdapat perbedaan. Asas merupakan dasar pemikiran yang umum dan abstrak, ide atau konsep dan tidak mempunyai sanksi, sedangkan norma adalah aturan yang konkrit, penjabaran dari ide dan mempunyai sanksi. Pada kenyataannya, asasasas umum pemerintahan yang layak ini meskipun merupakan asas namun tidak semuanya merupakan pemikiran yang umum dan abstrak dan beberapa halmuncul sebagai aturan hukum yang konkrit atau tertuang secra tersurat dalam pasal undang-undang, serta mempunyai sanksi tertentu. Berkenaan dengan hal ini, SF. Marbun mengatakan bahwa norma yang berlaku dalam kehidupan masyarakat umumnya diartikan sebagai peraturan, baik yang tertulis maupun yang tidak tertulis yang mengatur bagaimana manusia seyogyanya berbuat. Karena itu pengertian norma (kaedah hukum) dalam arti sempit mencakup asas-asas hukum dan peraturan hukum konkrit, sedangkan dalam arti luas pengertian pengertian norma ialah suatu sistem hukum yang berhubungan satu sama lainnya. ${ }^{8}$ Asas hukum merupakan sebagian dari kejiwaan manusia yang merupakan cita-cita yang hendak diraihnya. Dengan demikian apabila asas-asas umum pemerintahan yang layak dimaknakan sebagai asas atau sendi hukum, maka asas-asas umum pemerintahan yang layak dapat dimaknakan sebagai asas hukum yang bahannya digali dan ditemukan dari unsur susila, didasarkan pada moral sebagai hukum riil, bertalian erat dengan etika, kesopanan dan kepatutan berdasarkan norma yang berlaku. Selain itu Jazim Hamidi mengatakan bahwa sebagian asas-asas umum pemerintahan yang layak masih merupakan asas hukum dan sebagian lainnya telah menjadi norma hukum atau kaidah hukum.

Sebagai norma hukum, paling tidak asasasas umum pemerintahan yang layak mempunyai pengaruh pada tiga bidang: pertama, pada bidang

8 SF. Marbun, 2001, Pemebentukan, Pemberlakuan dan Peranan Asas-asas Umum pemerintahan Yang Layak dalam penafsiran dan penerapan dari ketentuan-keten${ }^{9}$ tuan peraturan perundang-undangan. Kedua, pada bidang pembentukan beleid pemerintah di mana organ pemerintah diberi kebebasan kebijaksanaan oleh peraturan perundang-undangan atau tidak terdapat ketentuan-ketentuan yang membatasi kebebasan kebijaksanaan yang akan dilakukan. Ketiga, pada waktu pelaksanaan kebijaksanaan.

\section{Arti Penting Asas-asas Umum Pemerintahan Yang Layak}

Pada awal kemunculannya, asas-asas umum pemerintahan yang layak hanya dimaksudkan sebagai sarana perlindungan hukum (rechtsbescherming) warga negara dari tindakan pemerintah yaitu sebagai dasar penilaian dalam peradilan dan uapaya administrasi, di samping sebagai norma hukum tidak tertulis bagi tindakan pemerintahan. Namun dalam perkembangannya, keberadaan asas-asas umum pemerintahan yang layak mempunyai makna yang lebih penting dari sekedar sebagai sarana kontrol. Arti penting mengenai keberadaan asas-asas umum pemerintahan yang layak tersebut, menurut Indroharto disebabkan oleh beberapa hal: pertama, karena asas-asas umum pemerintahan yang layak dianggap merupakan bagian darihukum positif yang berlaku. Kedua, karena asas-asas umum pemerintahan yang layak merupakan norma-norma di dalam hukum tertulis dan tidak tertulis. Ketiga, karena asas-asas umu pemerintahan yang layak dapat dijadikan alasan untukmengajukan gugatan dan akhirnya asas-asas umum pemerintahan yang layak dijadikan "alat uji" oleh hakim administrasi untuk menilai sah tidaknya atau batal tidaknya keputusan administrasi negara.

Asas-asas umum pemerintahan yang layak dalam perkembangannya memiliki arti penting dan fungsi sebagai berikut: Pertama, Bagi administrasi negara, bermanfaat sebagai pedoman dalam melakukan penafsiran dan penerapan ter-

menjelmakan Pemerintahan Yang Baik dab Bersih di Indonesia, Disertasi, Universitas Padjajaran, hlm. 72 
hadap ketentuan-ketentuan perundang-undangan yang bersifat sumir, samar atau tidak jelas. Kecuali itu sekaligus membatasi dan menghindari kemungkinan administrasi negara mempergunakan freies ermessen atau melakukan kebijaksanaan yang jauh menyimpang dari ketentuan perundang-undangan. Dengan demikian administrasi negara diharapkan terhindar dari perbuatan onrechtmatigedaad, detournement de pouvoir, abus de droit dan ultravirus. Kedua, bagi warga masyarakat, sebagai pencari keadilan, asas-asas umum pemerintah yang layak dapat dipergunakan sebagai dasar gugatan. Ketiga, bagi hakim Tata usaha negara dpat dipergunakan sebagai alat uji dan membatalkan keputusan yang dikeluarkan badan atau pejabat tata usaha negara. Keempat, Asas-asas umum pemerintahan yang layak juga berguna bagi badan legislatif dalam merancang suatu undang-undang.

Meskipun awalnya keberadaan keberadaan asas-asas umum pemerintahan yang layak belum memiliki sandaran yuridis formal, akan tetapi dalam praktek peradilan terutama pada peradilan tata usaha negara asas-asas tersebut telah diterapkan. Sebenarnya asas-asas tersebut dapat digunakan dalam praktek peradilan di Indonesia karena memiliki sandaran dalam Pasal 14 ayat (1) UU No. 14 Tahun 1970 tentang kekuasaan kehakiman: "Pengadilan tidak boleh menolak untuk memeriksa dan mengadili sesuatu perkara yang diajukan dengan dalih bahwa hukum tidak atau kurang jelas, melainkan wajib untuk memeriksa dan mengadilinya". Dalam Pasal 27 ayat (1) UU No. 14 Tahun 1970 ditegaskan: "Hakim sebagai penegak hukum dan keadilan wajib menggali, mengikuti dan memahami nilai-nilai hukum yang hidup dalam masyarakat". Dengan ketentuan pasal ini maka asas-asas ini memiliki peluang untuk digunakan dalamproses peradilan administrasi di Indonesia. Seiring dengan perjalanan waktu dan perubahan politik Indonesia, asas-asas ini kemudian muncul dan dimuat dalam suatu undang-undang yaitu UU No. 28 Tahun 1999 tentang Penyelenggaraan Negara yang Bersih dan Bebas dari Korupsi, Kolusi dan Nepotisme. Dengan format yang ber- beda dengan asas-asas umum pemerintahan umum yang layak dari negeri Belanda, dalam Pasal 3 UU No. 28 Tahun 1999 disebutkan beberapa asas umum penyelenggaraan negara yaitu: asas kepastian hukum, asas tertib penyelenggaraan negara, asas kepentingan umum, asas keterbukaan, asas proposionalitas, asas profesionalitas dan asas akuntabilitas. Penjelasan undang-undang tersebut terdapat keterangan sebagai berikut: asas kepastian hukum adalah asas dalam negara hukum yang mengutamakan landasan peraturan perundang-undangan, kepatutan dan keadilan dalam setiap kebijakan penyelenggara negara. Asas tertib penyelenggaraan negara adalah asas yang menjadi landasan keteraturan, keserasian dan keseimbangan dalam pengendalian penyelenggara negara. Asas kepentingan umum adalah asas yang mendahulukan kesejahteraan umum dengan cara yang aspiratif, akomodatif dan selektif. Asas keterbukaan adalah asas yang membuka diri terhadap hak masyarakat untuk memperoleh informasi yang benar, jujur dan tidak diskriminatif tentang penyelenggaraan negara dengan tetap memperhatikan perlindungan atas hak asasi pribadi, golongan dan rahasia negara. Asas proposionalitas asas yang mengutamakan keseimbangan antara hak dan kewajiban penyelenggara negara. Asas profesionalitas adalah asas yang mengutamakan keahlian yang berlandaskan kode etik dan ketentuan peraturan perundang-undangan yang berlaku. Asas akuntabilitas adalah asas yang menentukan bahwa setiap kegiatan dan hasil akhir dari kegiatan penyelenggara negara harus dapat dipertanggungjawabkan kepada masyarakat atau rakyat sebagai pemegang kedaulatan tertinggi negara sesuai dengan ketentuan peraturan perundang-undangan yang berlaku.

Asas-asas yang tercantum dalam UU No. 28 Tahun 1999 tersebut ditujukan untuk perkara penyelenggara negara secara keseluruhan, sementara asas-asas dalam asas-asas umum pemerintahan yang layak pada dasarnya hanya ditujukan pada algemeen beginselen van behoorlijk bestuur, bukan regering atau overheid, yang mengandung arti pemerintah dalam arti luas. Oleh 
karena itu, dalam kaitannya dengan proses peradilan, asas-asas yang terdapat dalam UU No. 28 Tahun 1999 tidak memiliki konsekuensi hukum yang sama dengan asas-asas umum pemerintahan yang layak, yang secara aktual telah dijadikan sebagai salah satu dasar penilaian oleh hakim. Dengan kata lain, asas-asas yang terdapat dalam UU No. 28 Tahun 1999 lebih merupakan etika dalam penyelenggaraan kenegaraan, bukan sebagai kaidah hukum.

\section{Implementasi Asas-asas Umum Pemerintahan Yang Layak/Baik dalam Peradilan Adminis- trasi}

Menurut Roescoe Pound, ada beberapa langkah yang biasa dilakukan hakim pada saat mengadili suatu perkara di Pengadilan yaitu: menemukan hukum, menafsirkan hukum dan menerapkan hukum. ${ }^{10}$ Dalam konteks pembahasan ini yang akan disoroti adalah khusus tentang penerapan hukumnya termasuk penerapan asas-asas umum pemerintahan yang layak. Istilah pe-nerapan hukum dalam praktek di pengadilan se-ring disamakan dengan istilah penemuan hukum dan penciptaan hukum atau pembentukan hukum, padahal masing-masing pengertian dari ketiganya mempunyai perbedaanperbedaan. Philipus M. Hadjon dalam suatu kajiannya mengenaiilmu hu-kum normatif mengatakan: filsafat hukum, asas hukum, teori hukum dan dogmatik hukum pada akhirnya harus diarahkan kepada praktek hukum. Praktek hukum menyangkut dua aspek utama yaitu pembentukan hukum dan penerapan hu-kum.

Menurut Hans kelsen dalam bukunya "Geberal Theory of law and State" diterjemahkan oleh Soemardi menyebutkan, bahwa pembentukan hukum itu selalu merupakan penerapan hukum. Konsep ini sama sekali bukan merupakan kebalikan yang mutlak, seperti yang diajukan oleh teori tradisional. Doktrin tradisional terutama sekali memandang keputusan pengadilan dan fungsi pengadilan sebagai suatu penerapan hukum. Ter-

10 Roescoe Pound, 1963, "An Introdukction to The Philosophy of Law" Diterjemahkan Moh. Radjab, 1963, Suatu Pengantar ke Filsafat Hukum, Jakarta: Bhartara, 1963, hlm. 67 bukti tatkala menyelesaikan suatu sengketa antara dua belah pihak atau tatkala menghukum seseorang tergugat dengan suatu sanksi (hukuman), maka pengadilan menerapkan suatu norma umum dari hukum undang-undang atau kebiasaan. Hal ini memang benar tetapi secara bersamaan pengadilan melahirkan suatu norma khusus yang menetapkan bahwa suatu sanksi terkhusus ini berhubungan dengan norma-norma umum seperti undang-undang berhubungan dengan konstitusi. Jadi fungsi hakim di pengadilan seperti pembuat undang-undang yaitu pembuat dan penerap hukum.

Dalam kebiasaan praktek hukum di pengadilan, Sudikno Mertokusumo menambahkan satu aspek lagi, yaitu aspek penemuan hukum. Penemuan hukum oleh hakim bukan semata-mata hanya penerapan peraturan-peraturan hukum terhadap peristiwa konkret tetapi sekaligus juga penciptaan dan pembentukan hukumnya. Penemuan hukum diartikan sebagai proses pembentukan hukum oleh hakim atau petugas-petugas hukum lainnya yang diberi tugas untuk melaksanakan hukum terhadap peristiwa-peristiwa hukum yang konkrit. ${ }^{11}$

Secara teknis operasional, bahwa proses yang ditempuh oleh hukum administrasi negara pada saat menerapkan asas-asas umum pemerintahan yang layak sebagai alat uji terhadap keputusan administrasi negara mempunyai beberapa unsur kesamaan dengan proses penerapan hukum di pengadilan perdata. Proses penerapan hukum (asas-asas umum pemerintahan yang layak) dalam penyelesaian sengketa di pengadilan administrasi (dari pemeriksaan perkara sampai pada pengambilan putusan) paling tidak melalui tiga tahapan seperti dibawah ini:

Pertama, tahap pengumpulan fakta. Sebelum memasuki tahap ini, di suatu proses administratif, di antaranya dengan penelitian administrasi oleh staf kepaniteraan diikuti oleh proses dimissal dan pemeriksaan persiapan. Setelah proses ini selesai dilanjutkan dengan pemeriksaan sidang biasa dengan hakim majlis atau hakim

11 Sudikno Mertokusumo, 1988, Mengenal Hukum (Suatu Pengantar), Edisi kedua, Yogyakarta: Liberty, hlm. 136 
tunggal. Pada tahap inilah yang disebut tahap pengumpulan fakta. Tugas hakim adalah melakukan seleksi terhadap keseluruhan peristiwa dan melakukan pembuktian dengan alat-alat bukti yang tersedia, guna memastikan kebenarannya. Tahap ini penting karena dari sinilah hakim dituntut untuk sungguh-sungguh dapat meyakini bahwa peristiwa yang sudah dikonstatirnya itu obyektif, sesuai dengan fakta-fakta yang ada dan dari sini pula putusan hakim harus disandarkan. Dalam hukum acara perdata,tahap ini sering disebut tahap mengkonstatir. Atau secara metodologis termasuk dalamkerangka pendekatan induktif.

Kedua, tahap mengidentifikasi hukum. Pada tahapini hakim adminstrasi melakukan suatu penilaian/pengujian terhadap fakta hukum atau peristiwa hukum yang sudah dikonstatirnya, kemudian dikualifisir masuk pada hubungan hukum mana. Dalam hukum acara perdata, tahap ini sering disebut tahap mengkualifisir. Berarti hakim sudah masuk pada tahap penerapan hukum (termasuk penerapan asas-asas umum pemerintahan yang layak), atau secara metodologis memasuki langkah deduktif. Langkah awalnya hakim melakukan identifikasi aturan hukum dan melakukan interpretasi terhadap aturan hukum yang sekiranya dapat diterapkan dalam, peristiwa konkrit. Di samping menerapkan juga kaidah hukum tidak tertulis (berupa asas-asas umum pemerintahan yang layak) untuk menguji keabsahan keputusan administrasi negara. Hasil identifikasi hukum yang ditindaklanjuti oleh penerapan hukum biasanya dirumuskan dalam pertimbangan hukum hakim.

Ketiga, tahap merumuskan asas-asas umum pemerintahan yang layak. Pada tahap ini, hakim administrasi teleha mengetahui pokok senketanya, juga sudah memberikan pertimbangan hukum mengenai penerapan asas-asas umum pemerintahan yang layak. Dengan demikian, hakim administrasi tinggal menentukan apakah keputusan administrasi negara yang disengketakan itu bertentangan dengan asas-asas umum pemerintahan yang layak atau tidak dan asas mana dari asas-asas umum pemerintahan yang layak yang dilanggar. Setelah itu hakim administrasi dapat menentukan keabsahannya keputusan administrasi negara melalui putusannya. Dalam hukum acara perdata tahapacara perdata taha perumusan dan penentuan putusan ini sering disebut tahap mengkonstituir.

Dalam penerapan asas-asas umum pemerintahan yang layak sebagai alat uji terhadap keabsahan keputusan administrasi negara dapat didekati dengan tiga sudut pandang untuk membahasnya yaitu historis, teoritis dan yuridis praktis.

Pertama, dari sudut pandang historis. Pendekatan historis dalam suatu kajian ilmu hukum, biasanya mengarah pada pembuktian mengenai sejarah hukum keberadaannya dan sejarah pengaturannya. Sejarah hukum telah menjelaskan bahwa asas-asas umum pemerintahan yang layak dengan sifatnya yang masih abstrak, tidak tertulis dan tidak ada sanksi, mempunyai daya keberlakuan secara universal serta diterima oleh dunia internasional. Tetapi pada saat penerapannya dalam suatu negara ia sangat dipengaruhi oleh idiologi, politik, budaya dan hukum negara yang bersangkutan.

Kedua, dari sudut pandang teoritis. Pada prinsipnya, hakim tidak diperkenankan menguji "beleid" (kebijakan) pemerintah, karena beleid itu didasarkan kepada "asas Nach Preies Ermessen" dalam rangka menjalankan service public. ${ }^{12}$ Walaupun demikian, penyelengaraan asas Nach Freies Ermessen itu tidak boleh menyimpang dari tujuan diberikannya wewenang, juga tidak boleh bertentangan dengan norma-norma hukum dan nilai kepatutan yang ada dalam masyarakat. Hal ini sejalan dengan teori analitical jurisprudence yang dikemukakan oleh John Austin, bahwa disamping norma hukum tertulis (positive law), masih ada pranata hukum tidak tertulis (positive morality) yang juga harus dihormati. Pada aspek yang terakhir inilah, asas-asas umum pemerintahan yang layak mempunyai peran yang sangat urgen sekaligus pemerintah menafikan asas-asas umum pemerintahan yang layak, maka akan berbalik menjadi sebab dapat dibatalkannya kebijakan tersebut oleh hakim administrasi. Jadi

12 Op.cit, hlm 241 
terhadap beleid yang bertentangan dengan norma hukum dan asas kepatutan, maka beleid semacam itu dapat diuji melalui mekanisme yudisial review dan pengujian oleh hakim adminstrasi. Mekanisme yudisial review, dilakukan terhadap beleid yang sifatnya pengaturan secara umum. Adapun mekanisme pengujian oleh hakim administrasi, dilakukan terhadap kebijakan dalam bentuk penetapan tertulis (beschikking) yang memenuhi unsur-unsur individual, konkret dan final serta merugikan seseorang dan/atau badan hukum perdata. Obyek utama dalam pembahasan ini ini adalah pengujian oleh hakim administrasi terhadap keputusan (beschikking) administrasi negara yang berkaitan dengan penerapan asas-asas umum pemerintahan yang layak. Perlu diingat, tidak semua keputusan admi-nistrasi negara itu dapat diuji dengan alat uji berupa asas-asas umum pemerintahan yang layak, melainkan hanya keputusan dalam bentuk "vrij beschikking" (keputusan bebas). Dengan demikian dapatlah disimpulkan bahwa secara teoritis hakim adminstrasi dapat menerapkan asas-asas umum pemerintahan yang layak sebagai alat uji terhadap keputusan administrasi negara.

Menurut M.Koesnoe, dalam menerapkan asas hukum (termasuk asas-asas umum pemerintahan yang layak) harus dilakukan secara deduktif terlebih dahulu, artinya asas khusus yang dikhususkan lagi pada bidang hukumnya yang bersangkutan. Kemudian didedusir lagi kedalam kaidah substansinya dan didedusir lagi menjadi kaidah kasusnya. Setelah itu baru dilakukan penerapan kaidah kasus dalam kasus konkret oleh hakin. Dengan demikian untuk dapat menerapkan asas-asas umum pemerintahan yang layak ke dalam kasus konkret, terbentang jarak yang begitu jauh dan berliku yang harus ditempuh oleh seorang hakim.

Ketiga, dari sudut yuridis praktis. Sebelum peradilan administrasi terbentuk segala sengketa administrasi negara diselesaikan oleh peradilan umum akan tetapi setelah peradilan administrasi terbentuk kompetensi menyelesaikan sengketa administrasinya beralih kepada peradilan administrasi. Bahwa frekwensi seng- keta yang masuk ke pengadilan dari tahun ke tahun mengalami kenaikan, termasuk putusanputusan hakim yang menerapkan asas-asas umum pemerintahan yang layak. Keberadaan asas-asas umum pemerintahan yang layak sedang menuju ke arah diterimanya oleh masyarakat dan atau ke dalam hukum positif Indonesia. Dalam menghadapi kenyataan penerapan asas-asas umum pemerintahan yang layak, Mahkamah Agung telah mengeluarkan Surat Keputusan via Ketua Muda Mahkamah Agung Lingkungan Tata Usaha Negara No. 052/Td/TUN/III/1992 tertanggal 24 maret 1992 ( Butir V diktum 1 ) yang berbunyi :

Di dalam hal hakim memeprtimbangkan adanya asas-asas umum penyelenggaraan pemerintahan yang layak sebagai alasan pembatalan penetapan,maka hal tersebut tidak perlu dimasukkan dalam diktum putusannya, melainkan cukup dalam pertimbangan putusan dengan menyebutkan asas mana dari asas-asas umum penyelenggaraan pemerintahan yang layak yang dilanggar.

Menurut Philipus M. Hadjon, ada dua hal yang menarik dari surat keputusan tersebut dalam kaitannya dengan asas-asas umum penyelenggaraan pemerintahan yang layak yaitu : asas-asas umum penyelenggaraan pemerintahan yang layak hanya mendapat tempat dalam pertimbangan diktum serta dalam pertimbangan harus disebutkan asas-asas mana yang dilanggar. M. Laica marzuki menafsirkan bahwa hakim administrasi hanya dapat menjadikan asas-asas umum penyelenggaraan pemerintahan yang layak sebagai salah satu dasar pertimbangan hukum untuk menguji keabsahan keputusan administrasi negara. Namun dalam perkembangannya sekarang asas-asas umum pemerintahan yang baik bisa menjadi dasar/alasan untuk menggugat terhadap keputusan tata usaha negara. Hal tersebut diatur dalam Pasal 53 ayat (2) Undang-undang Nomor 9 Tahun 2004 tentang perubahan atas Undangundang Nomor 5 Tahun 1986 tentang Peradilan Tata Usaha Negara yang berbunyi : "alasan-alasan yang dapat digunakan dalam gugatan sebagaimana dimaksud ayat (1) adalah : 
a. Keputusan Tata Usaha Negara yang digugat itu bertentangan dengan peraturan perundang-undangan yang berlaku;

b. Keputusan Tata Usaha Negara yang digugat itu bertentangan dengan asas-asas umum pemerintahan yang baik..

\section{PENUTUP}

Secara teknis operasional, bahwa proses yang ditempuh oleh hukum administrasi negara pada saat menerapkan asas-asas umum pemerintahan yang layak sebagai alat uji terhadap keputusan administrasi negara mempunyai beberapa unsur kesamaan dengan proses penerapan hukum di pengadilan perdata. Proses penerapan hukum (asas-asas umum pemerintahan yang layak) dalam penyelesaian sengketa di pengadilan administrasi (dari pemeriksaan perkara sampai pada pengambilan putusan) paling tidak melalui tiga tahapan seperti dibawah ini:

Pertama, tahap pengumpulan fakta. Sebelum memasuki tahap ini, di suatu proses administratif, di antaranya dengan penelitian administrasi oleh staf kepaniteraan diikuti oleh proses dimissal dan pemeriksaan persiapan. Setelah proses ini selesai dilanjutkan dengan pemeriksaan sidang biasa dengan hakim majlis atau hakim tunggal. Pada tahap inilah yang disebut tahap pengumpulan fakta. Tugas hakim adalah melakukan seleksi terhadap keseluruhan peristiwa dan melakukan pembuktian dengan alat-alat bukti yang tersedia, guna memastikan kebenarannya. Tahap ini penting karena dari sinilah hakim dituntut untuk sungguh-sungguh dapat meyakini bahwa peristiwa yang sudah dikonstatirnya itu obyektif, sesuai dengan fakta-fakta yang ada dan dari sini pula putusan hakim harus disandarkan. Dalam hukum acara perdata, tahap ini sering disebut tahap mengkonstatir. Atau secara metodologis termasuk dalamkerangka pendekatan induktif.

Kedua, tahap mengidentifikasi hukum. Pada tahapini hakim adminstrasi melakukan suatu penilaian/pengujian terhadap fakta hukum atau peristiwa hukum yang sudah dikonstatirnya, kemudian dikualifisir masuk pada hubungan hukum mana. Dalam hukum acara perdata, tahap ini se- ring disebut tahap mengkualifisir. Berarti hakim sudah masuk pada tahap penerapan hukum (termasuk penerapan asas-asas umum pemerintahan yang layak), atau secara metodologis memasuki langkah deduktif. Langkah awalnya hakim melakukan identifikasi aturan hukum dan melakukan interpretasi terhadap aturan hukum yang sekiranya dapat diterapkan dalam, peristiwa konkrit. Di samping menerapkan juga kaidah hukum tidak tertulis (berupa asas-asas umum pemerintahan yang layak) untuk menguji keabsahan keputusan administrasi negara. Hasil identifikasi hukum yang ditindaklanjuti oleh penerapan hukum biasanya dirumuskan dalam pertimbangan hukum hakim.

Ketiga, tahap merumuskan asas-asas umum pemerintahan yang layak. Pada tahap ini, hakim administrasi teleha mengetahui pokok senketanya, juga sudah memberikan pertimbangan hukum mengenai penerapan asas-asas umum pemerintahan yang layak. Dengan demikian, hakim administrasi tinggal menentukan apakah keputusan administrasi negara yang disengketakan itu bertentangan dengan asas-asas umum pemerintahan yang layak atau tidak dan asas mana dari asas-asas umum pemerintahan yang layak yang dilanggar. Setelah itu hakim administrasi dapat menentukan keabsahannya keputusan administrasi negara melalui putusannya. Dalam hukum acara perdata tahap acara perdata taha perumusan dan penentuan putusan ini sering disebut tahap mengkonstituir.

\section{DAFTAR PUSTAKA}

H.R. Ridwan. 2002. Hukum Administrasi Negara. Yogyakarta: Penerbit UII Press;

Hadjon, Philipus M. 1993. Pengantar Hukum Administrasi Negara Indonesia, Yogyakarta: Gadjah Mada University Press;

Hamidi, Jazim. 1999. Penerapan Asas-asas Umum Penyelenggaraan Pemerintahan yang Layak (AAUPL) di Lingkungan Peradilan Administrasi Indonesia, Bandung: Citra aditya Bakti; 
19 Pena Justisia: Media Komunikasi dan Kajian Hukum Vol. 17, No. 1, 2017

Lotulung, Paulus Effendi. 1994. Perbandingan Hukum Administrasi Negara. Bandung: PT. Citra aditya Bakti;

Marbun, SF. 1997. Peradilan Administrasi dan Upaya Administratif di Indonesia, Yogyakarta: Liberty;

Marbun, SF. 2001. Pemebentukan, Pemberlakuan dan Peranan Asas-asas Umum pemerintahan Yang Layak dalam menjelmakan Pemerintahan Yang Baik dab Bersih di Indonesia. Disertasi. Universitas Padjajaran.

Mertokusumo, Sudikno. 1988. Mengenal Hukum (Suatu Pengantar). Edisi kedua. Yogyakarta: Liberty;

Pound, Roescoe. 1963. "An Introdukction to The Philosophy of Law" Diterjemahkan Moh. Radjab, 1963. Suatu Pengantar ke Filsafat Hukum. Jakarta: Bhartara; 